\title{
The Equation for the Optimum Dosage of Coagulant for Water Treatment Plant
}

\author{
Ljiljana TAKIĆ, Dejan VASOVIĆ, Srdjan MARKOVIĆ, Zijah BURZIĆ
}

\begin{abstract}
This paper shows the importance of the equation for the optimum dosage of coagulant and its application to water treatment plant. The optimum coagulant dose during the operation of the water treatment plant "Gorina" in Serbia was determined in a laboratory by means of the jar-test, which fully simulates the conditions of flocculation chambers in the facility. Experimental data fitting yielded a polynomial equation that can be used for the determined coagulant doses. In general, without a jar test, the equation can be used to reliably determine the optimum coagulant dose for application in the water treatment plant, which will purify raw water to a proper inter-stage turbidity value, and will guarantee that the treated water quality will correspond to the Regulation on Hygienic Quality of Drinking Water. The presented analysis of trial run results for the water treatment plant "Gorina" in Serbia showcases the benefits of applying the equation of optimum coagulant doses to achieve top drinking water quality.
\end{abstract}

Keywords: drinking water; optimum coagulant dose; water treatment plant

\section{INTRODUCTION}

There are no alternatives to drinking water. Utilization of surface water resources for urban water supply primarily depends on raw water quality, the proximity of industrial and other polluters, risk of unforeseen contamination, water source capacities, and the duration of transport of treated water both to the primary consumers like households and industry and secondary consumers like fire prevention services [1]. Based on the available analyses of river water quality and the experience of similar existing systems both in Serbia and in Europe, the water treatment plant "Gorina" in Leskovac, Serbia was designed as a modern technological process of raw water treatment to drinking water standard. The primary purpose of the regional water supply system "Barje" is to supply quality drinking water to the City of Leskovac and the surrounding areas. Raw water from the accumulation lake Barje is sent to the "Gorina" treatment plant, where it is treated to drinking water standard prescribed by the Regulation on Hygienic Quality of Drinking Water. In addition, due to annual variations in the river level, the accumulation lake effectively protects the city against potential floods. The Serbian environmental protection agency constantly controls water quality in accumulation lakes and surface waters and monitors the contamination trends in order to preserve water resources [2-4].

The optimum procedure for water treatment in "Gorina" facilities was defined based on a series of physicochemical and microbiological analyses of the Veternica river water on the accumulation profile. The designed modern and flexible production line contains the processing stages of pre-ozonation, coagulation, flocculation, sedimentation, filtration, and disinfection, respectively, which implies that the purification process adapts to the raw water quality through optimum doses of chemicals during the plant's operation. The primary task of the envisaged technological process is the removal of suspended and organic matter, iron, manganese, dyes, ammonia, nitrites, and trihalomethane precursors, as well as water disinfection [5].

The aim of the analysis of a one-year trial run and the determination of optimum coagulant dose by the equation is to realistically assess the reliability and efficiency of a facility for raw water treatment to drinking water standard, for which the water treatment plant "Gorina" in Leskovac, Serbia served as the example.

\section{MATERIAL AND METHOD}

The water treatment plant "Gorina" in Leskovac, Serbia is a modern production line for treating raw water from the accumulation lake Barje to drinking water standard. The accumulation lake Barje, with its total raw water capacity of $40,670,000 \mathrm{~m}^{3}$ is intended to meet the current and future water supply needs of the City of Leskovac and the surrounding areas. The plant is located $5.5 \mathrm{~km}$ downstream from the dam. The altitude of the water treatment plant allows the treated water to be transported by gravitational force alone to the drinking water reservoir, capacity 25,000 $\mathrm{m}^{3}$, in Rudarska Kosa near Leskovac [5].

The plant's production line was designed to comprise the following processing stages: pre-ozonation (with raw water $\mathrm{pH}$ correction if needed), coagulation, flocculation, sedimentation, filtration by rapid sand filters, and disinfection in the treated water tank. Each stage is equally important. The raw water treatment processes are supposed to remove suspended solids, organic and inorganic chemical components, bacteria, and contaminants, which give off unpleasant taste and smell. Another point worth highlighting is the attention given to environmental requirements, as the plant provides full treatment of sewage leachate.

In other words, the plant was designed to offer a modern technological process for treating water from the accumulation lake, and its reliability and efficiency is to be assessed by analysing the trial run over a one-year period, from one month of May to the next [5].

The efficiency of the technology for treating water to drinking water standard depends heavily on the quality of raw water. The raw water quality, average monthly values, the observed one-year trial run period is shown in Tab. 1.

The best raw water quality during the trial run was in February, with the lowest turbidity of 1.84 NTU on average, because there were no influents of melted snow so the turbidity levels were stable. The worst raw water quality was registered in March, when the average turbidity of the accumulation lake was 19.07 NTU, with the highest recorded turbidity of 47.7 NTU. Snow from the nearby hills was melting in March, which created new influents, leading to abrupt lake turbidity. Average raw water $\mathrm{pH}$ 
levels ranged from 7.45 in September to 7.83 in December. The highest temperature of raw water was measured in October and the lowest in February, $12.8^{\circ} \mathrm{C}$ and $3.2{ }^{\circ} \mathrm{C}$, respectively. Using the data provided by the Serbian Environmental Protection Agency and applying different criteria of surface water quality classification, numerous assessments of water quality in the accumulation lake Barje have shown that the raw water quality is in keeping with the quality of water intended for water supply [6].

Table 1 Quality parameters of raw water

\begin{tabular}{|c|c|c|c|c|c|c|c|c|c|c|c|c|c|}
\hline 营 & 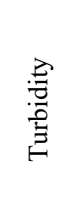 & $\stackrel{I}{2}$ & 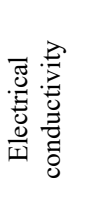 & 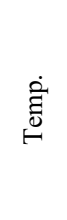 & $\begin{array}{c}\mathrm{KMnO}_{4} / \\
\mathrm{HPK}\end{array}$ & 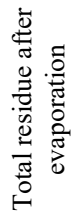 & 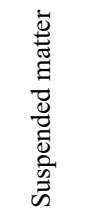 & 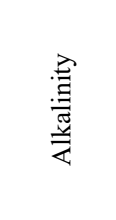 & $\begin{array}{c}\text { Dissolved } \\
\mathrm{O}_{2}\end{array}$ & 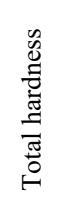 & $\mathrm{Ca}$ & BOD & $\begin{array}{l}\text { UV } \\
\text { ekst. }\end{array}$ \\
\hline Unit & NTU & & $\mu \mathrm{S} / \mathrm{cm}$ & ${ }^{\circ} \mathrm{C}$ & $\mathrm{mg} / \mathrm{l}$ & $\mathrm{mg} / \mathrm{l}$ & $\mathrm{mg} / \mathrm{l}$ & $\begin{array}{c}\mathrm{ml} 0.1 \mathrm{M} \\
\mathrm{HCl} / 1\end{array}$ & $\mathrm{mg} / \mathrm{l}$ & ${ }^{\circ} \mathrm{DH}$ & $\mathrm{mg} / \mathrm{l}$ & $\mathrm{mg} / 1$ & $\mathrm{~cm}^{-1}$ \\
\hline May & 2.47 & 7.80 & 251 & 10.6 & $9.14 / 2.31$ & 125 & 9.13 & 22.01 & $9.59 / 99.73$ & 7.75 & 33.38 & $<1$ & 0.062 \\
\hline June & 2.98 & 7.68 & 252 & 10.9 & $8.33 / 2.11$ & 126 & 8.80 & 22.07 & $9.18 / 94.51$ & 7.71 & 32.60 & $<1$ & 0.064 \\
\hline July & 2.67 & 7.64 & 253 & 10.3 & $8.36 / 2.12$ & 126 & 9.45 & 22.41 & $10.14 / 104.5$ & 7.17 & 31.00 & $<1$ & 0.060 \\
\hline Aug. & 2.95 & 7.52 & 253 & 11.8 & $7.88 / 1.99$ & 126 & 10.00 & 22.53 & $7.80 / 74.31$ & 7.04 & 30.28 & $<1$ & 0.063 \\
\hline Sept. & 4.77 & 7.45 & 254 & 10.6 & $7.91 / 2.00$ & 127 & 10.76 & 22.50 & $8.79 / 80.80$ & 7.14 & 30.48 & $<1$ & 0.070 \\
\hline Oct. & 4.12 & 7.50 & 262 & 12.8 & $8.09 / 2.05$ & 131 & 10.14 & 24.03 & $9.35 / 89.05$ & 7.16 & 31.06 & $<1$ & 0.065 \\
\hline Nov. & 2.55 & 7.79 & 263 & 10.0 & $8.67 / 2.19$ & 136 & 10.34 & 25.16 & $10.71 / 90.50$ & 7.55 & 32.60 & $<1$ & 0.055 \\
\hline Dec. & 3.05 & 7.83 & 277 & 7.00 & $7.76 / 196$ & 138 & 10.30 & 24.83 & $11.74 / 94.30$ & 7.70 & 33.90 & $<1$ & 0.059 \\
\hline Jan. & 4.34 & 7.76 & 271 & 4.8 & $7.73 / 1.95$ & 140 & 11.24 & 25.19 & $12.60 / 93.40$ & 7.74 & 33.42 & $<1$ & 0.059 \\
\hline Feb. & 1.84 & 7.75 & 284 & 3.2 & $7.88 / 1.99$ & 142 & 8.21 & 24.37 & $12.54 / 93.00$ & 7.62 & 33.48 & $<1$ & 0.056 \\
\hline March & 19.07 & 7.59 & 268 & 4.1 & $10.62 / 2.69$ & 134 & 12.97 & 22.53 & $11.04 / 86.30$ & 7.29 & 32.27 & $<2$ & 0.127 \\
\hline April & 12.79 & 7.80 & 207 & 7.2 & $12.98 / 3.28$ & 103 & 11.31 & 16.44 & $10.36 / 89.60$ & 6.08 & 25.27 & $<2$ & 0.136 \\
\hline May & 5.65 & 7.83 & 203 & 9.66 & $11.93 / 3.02$ & 101 & 8.52 & 17.15 & $10.49 / 88.70$ & 5.63 & 24.17 & $<2$ & 0.108 \\
\hline
\end{tabular}

\section{RESEARCH RESULTS}

Real-time determination of appropriate coagulant dosage under wide fluctuation of raw water quality in a water treatment plant is a challenging task due to nonlinearity relation between coagulant dosage and raw water characteristics [7]. The optimum coagulant dose during the operation of the water treatment plant "Gorina" was determined in a laboratory by means of the jar test, which fully simulates the conditions of flocculation chambers in the facility. The following parameters were set for the initial sample: water temperature, $\mathrm{pH}$ value, and turbidity. Each of the four jars was filled with 1,000 $\mathrm{ml}$ of water sample brought straight from the plant immediately after pre-ozonation, selected amounts of aluminium sulphate, and equal amounts of polyelectrolytes (determined within the projected values). Subsequently, the following actions were performed:

- at $200 \mathrm{r} / \mathrm{min}$ - dosing of chemicals (simulation of the hydraulic jump from the facility),

- at $120 \mathrm{r} / \mathrm{min}$ - intensive stirring for 3 minutes (simulation of the first flocculation chamber from the facility),

- at $45 \mathrm{r} / \mathrm{min}$ - stirring for 5 minutes (simulation of the second flocculation chamber from the facility),

- at $10 \mathrm{r} / \mathrm{min}$ - slow stirring for 10 minutes (simulation of the third flocculation chamber from the facility),

- $\quad$ settling for 30 minutes.

A total of four samples were tested with the selected determined doses of aluminium sulphate: $20 \mathrm{~g} / \mathrm{m}^{3}$ for the first sample, $23 \mathrm{~g} / \mathrm{m}^{3}$ for the second sample, $26 \mathrm{~g} / \mathrm{m}^{3}$ for the third sample, and $30 \mathrm{~g} / \mathrm{m}^{3}$ for the fourth sample, with a constant dose of anionic electrolyte. The volume of chemicals dosed into the jar with a pipette is calculated with the following expression:

$$
\text { Chemical }(\text { volume })=\frac{\text { Water sample volume }\left(\mathrm{m}^{3}\right) \times \text { dose of chemical }\left(\frac{\mathrm{g}}{\mathrm{m}^{3}}\right)}{\text { Solution concentration }\left(\frac{\mathrm{g}}{1}\right)}
$$

The determined doses of coagulant aluminium sulphate were prepared from the solution brought from the treatment process immediately after pre-ozonation. Aluminium sulphate solution concentration was determined indirectly by measuring the solution density with an aerometer and reading the corresponding value from the correlation table, which in this case was $4 \%$, i.e. $40 \mathrm{~g} / \mathrm{l}$. For the dose of polyelectrolyte from the facility of $0.22 \mathrm{~g} / \mathrm{m}^{3}$ and $0.05 \%$ solution concentration, i.e. $0.5 \mathrm{~g} / \mathrm{l}$, the calculated volume of the solution added to each sample was equal to $0.44 \mathrm{ml}$ of polyelectrolyte solution. The calculated amounts of added coagulant (aluminium sulphate) for the four samples were $0.50 \mathrm{ml}, 0.57 \mathrm{ml}, 0.65$ $\mathrm{ml}$, and $0.75 \mathrm{ml}$, respectively. Raw water temperature at the beginning of the jar test was $5.8^{\circ} \mathrm{C}$, but it increased during the test to reach $14.3{ }^{\circ} \mathrm{C}$ by the end of the test. The following observations were made after careful inspection of the manner of flocs formation, their appearance, and the speed of their settling:

- In samples 1 and 2 flocs were clear, large, gelatinous, and heavy. Good and quick settling.

- In sample 3, gelatinous flocs formed fastest; large number of flocs (relatively light) with slower but more thorough settling.

- Sample 4 had a milky cloudiness and smaller, slowsettling, flocs.

After completed clarification, turbidity was measured for all samples using the Hach $2100 \mathrm{~N}$ turbidimeter and the values for each sample, expressed in nephelometric turbidity units (NTU), are given in Tab. 2. 
Table 2 Results of sample analysis after jar test compared to raw water quality

\begin{tabular}{|c|c|c|c|c|}
\hline Sample & Temperature $\left({ }^{\circ} \mathrm{C}\right)$ & $\mathrm{pH}$ value & Measured turbidity (NTU) & Calculated turbidity (NTU) \\
\hline Raw water & 5.8 & 7.63 & 1.55 & 0.47 \\
\hline I & 14.3 & 7.18 & 0.38 & 0.470 \\
\hline II & 14.3 & 7.17 & 0.32 & 0.372 \\
\hline III & 14.3 & 7.12 & 0.35 & 0.327 \\
\hline
\end{tabular}

Analysis of the results indicates that the turbidity of raw water of 1.55 NTU was reduced in all samples after the jar test below the maximum allowed turbidity value prescribed by the Regulation on Hygienic Quality of Drinking Water. The determined coagulant dose of $26 \mathrm{~g} / \mathrm{m}^{3}$ for the third sample yields the lowest turbidity of $0.32 \mathrm{NTU}$ (evident in Fig. 1) and therefore provides the most efficient purification of a sample, which suggests that the dose would be optimal for application in the water treatment plant itself.

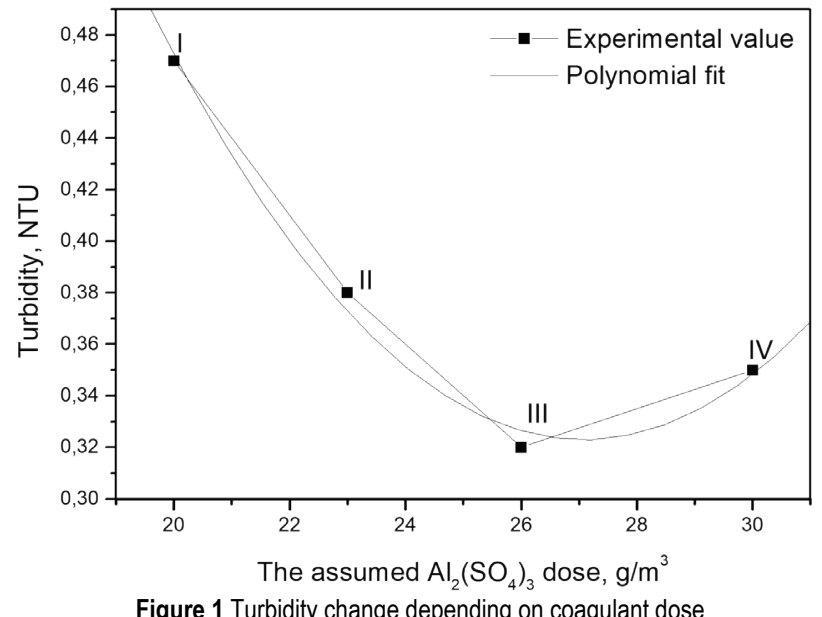

Software solution of fitting experimental data provides a polynomial equation that determines the optimum coagulant dose as the closest approximation:

$Y=2.511-0.162 \times X+0.003 \times X^{2}$

where: $Y$ - turbidity (NTU), $X$ - applied dose of coagulant (aluminium sulphate), $\mathrm{g} / \mathrm{m}^{3}$.

The equation yields satisfactory values upon verification of experimental data, so it unquestionably confirms the empirical results. Calculation and selection of the lowest turbidity value can help predict the best effect of coagulation and flocculation without a jar test, so it is possible to reliably determine the optimum coagulant dose to be applied in the plant based on 'theoretically' determined doses.

\section{DISCUSSION}

Water treatment plant "Gorina" in Serbia is a flexible production line which allows the process to adapt according to the quality of raw water from the accumulation lake Barje. The water goes through preozonation chambers, a hydraulic jump, and coagulation and flocculation chambers to the lamella clarifier, from where it continues to the filtration chamber to finally reach the treated water tank, where it is chlorinated and distributed to consumers. The modern procedure of surface water purification involves the dosing of the following chemicals: sulphuric acid for $\mathrm{pH}$ correction; ozone in preozonation; aluminium sulphate as a coagulant; anionic polyelectrolytes as flocculants; lime for decarbonisation; and chlorine for disinfection [5]. Raw water from the accumulation lake Barje goes into the plant at a capacity of $840 \mathrm{l} / \mathrm{s}$ and immediately upon entry is divided into two separate parallel clarification lines, each with a capacity of $420 \mathrm{l} / \mathrm{s}$. When there are two separate lines for the same flow of raw water, the time of contact and reaction is twice as long as with one clarification line, so the water is retained longer in the flocculation chambers and the clarifier, which ultimately improves clarification. Correction of the $\mathrm{pH}$ value in raw water was not performed with $1 \% \mathrm{H}_{2} \mathrm{SO}_{4}$ because the average $\mathrm{pH}$ values ranged from 7.45 to 7.83 over the observed period, which means they were satisfactory for uninterrupted coagulation and flocculation. In the pre-ozonation process, raw water was treated with $340 \mathrm{gO}_{3} / \mathrm{h}$, which is a dose of $0.39 \mathrm{gO}_{3} / \mathrm{m}^{3}$ for the average annual incoming water flow of $870 \mathrm{~m}^{3} / \mathrm{h}$, which falls within the range of projected values of a minimum of $0.5 \mathrm{gO}_{3} / \mathrm{m}^{3}$ to a maximum of $1.6 \mathrm{gO}_{3} / \mathrm{m}^{3}$ depending on raw water quality. Optimum doses of coagulants and flocculants were applied based on a jar test conducted on the water after preozonation. A comparative analysis has confirmed that they correspond to the projected minimum and maximum values from 10 to $80 \mathrm{~g} / \mathrm{m}^{3}$ of aluminium sulphate and from 0.1 to $0.5 \mathrm{~g} / \mathrm{m}^{3}$ of polyelectrolytes, respectively. The projected $10 \%$ solution concentration was not applied in the facility for aluminium sulphate dosing, because pumps with a dosing capacity of $4,000 \mathrm{l} / \mathrm{h}$ were installed for the designed plant capacity of $840 \mathrm{l} / \mathrm{s}$, so they would have to operate at low capacity and under a heavy load. However, adding twice the amount of service water for making the solution, with the same amount of aluminium sulphate, will result in a 5\% solution, which increases the dosing capacity and places a lighter load on the pumps. Accordingly, in the coagulation stage, a 5\% solution of aluminium sulphate was dosed at the point of the hydraulic jump, with the average dose of $26 \mathrm{~g} / \mathrm{m}^{3}$, flexibly corrected depending on raw water quality. It should be noted that the optimal dose of coagulant equation corresponds to the calculated value without jar-test. For the purpose of flocculation, a $0.1 \%$ solution of anionic polyelectrolyte was prepared and additionally diluted to be used as a $0.05 \%$ flocculate. The average optimum dose of flocculate over the analysed period was $0.22 \mathrm{~g} / \mathrm{m}^{3}$ of anionic polyelectrolyte. The raw water thus treated is then clarified through the lamella clarifier and distributed for filtration. The formed sludge in the clarifier is moved to the filter press by means of highpressure pumps, and the addition of a cationic polyelectrolyte helps form sludge cakes, which are then safely disposed of in a landfill. Average turbidity of clarified water that underwent filtration was 1.75 NTU as opposed to the varying turbidity values of raw water from 2 NTU to 48 NTU, which confirms the positive effect of 
the observed purification stage. The filtration process used eight dual-layer filter fields with mixed filling, which correct turbidity from $1.75 \mathrm{NTU}$ to $0.1 \mathrm{NTU}$. After filtration, the filtered water is channelled through collection channels to the pumping station from where it flows into the treated, clean water tanks. Water decarbonisation with lime is carried out in collection channels after filtration for the purpose of protecting the distribution network and correcting $\mathrm{pH}$ values, which is significant in case the water begins to exhibit corrosive tendencies. Finally, water is chlorinated at the point of entry into treated water tanks. In addition, the treated water that leaves the tanks also requires final or corrective chlorination in order to meet the requirements for residual chlorine required by the Regulation on Hygienic Quality of Drinking Water [9]. In the observed period, the average capacity of chlorine dosing was $660 \mathrm{~g} / \mathrm{h}$ in the main chlorination and $340 \mathrm{~g} / \mathrm{h}$ in the final, corrective, chlorination. Optimum average doses of chlorine were 0.76 $\mathrm{gCl} / \mathrm{m}^{3}$ before entry into treated water tanks and 0.41 $\mathrm{gCl} / \mathrm{m}^{3}$ upon leaving the tanks, which is much lower than the projected doses of $1.3 \mathrm{gCl} / \mathrm{m}^{3}$ in the main and 0.6 $\mathrm{gCl} / \mathrm{m}^{3}$ in the final chlorination, so less chlorine needed to be used. The average used dose of $0,76 \mathrm{gCl} / \mathrm{m}^{3}$ in the main chlorination yields $0.4 \mathrm{mg} / 1$ of residual chlorine, which suggests that ozone partially disinfects raw water and reduces chlorine use; consequently, the demand for chlorine during the trial run was $0.36 \mathrm{mgCl} / 1$, which was used to remove all the microorganisms remaining after preozonation, sedimentation, and filtration [9]. The results for the one-year period show that the values of standardized quality indicators for purified water were below the maximum allowed concentrations for drinking water [9]. During the trial run a total of 7,628,335 $\mathrm{m}^{3}$ of treated water was produced; since $387,998 \mathrm{~m}^{3}$ was used to wash the filters and for sanitary and other purposes, 7,240,337 $\mathrm{m}^{3}$ of drinking water was distributed to consumers at a rate of 229 $1 / \mathrm{s}$. The treatment procedure provided drinking water of proper quality, as a basic prerequisite for good health of the residents of Leskovac and the surrounding areas, in accordance with the current quality standards [9]. Tab. 3 shows the average monthly values of the examined parameters of quality indicators of treated water produced by a modern production line for drinking water over the observed trial run period.

Table 3 Quality parameters of treated water

\begin{tabular}{|c|c|c|c|c|c|c|c|c|c|c|c|c|c|c|}
\hline Month & Reg. & May & June & July & Aug. & Sep. & Oct. & Nov. & Dec. & Jan. & Feb. & Mar. & April. & May \\
\hline $\mathrm{T}^{\circ} \mathrm{C}$ & 8-12 & 11,9 & 13,6 & 14,4 & 14,5 & 11,4 & 12,8 & 10,1 & 7,3 & 5,0 & 3,7 & 5,3 & 8,7 & 10,7 \\
\hline Turb. NTU & 1 & 0,12 & 0,13 & $<0.1$ & $<0.1$ & 0,14 & 0,11 & 0,12 & $<0.1$ & $<0.1$ & $<0.1$ & 0,19 & $<0.1$ & 0,23 \\
\hline $\mathrm{pH}$ & $6,8-8,5$ & 7,30 & 7,31 & 7,29 & 7,24 & 7,18 & 7,21 & 7,52 & 7,57 & 7,53 & 7,50 & 7,29 & 7,28 & 7,4 \\
\hline $\mathrm{KMnO}_{4}, \mathrm{mg} / \mathrm{l}$ & 8 & 4,73 & 4,48 & 4,41 & 3,71 & 4,17 & 4,23 & 4,48 & 4,29 & 4,31 & 4,63 & 5,11 & 5,20 & 5,4 \\
\hline Alkalinity & & 20,03 & 20,52 & 20,59 & 20,85 & 20,79 & 22,09 & 24,18 & 23,64 & 23,52 & 23,48 & 20,50 & 14,01 & 15,18 \\
\hline $\begin{array}{c}\text { Electr. cond. } \\
\mu \mathrm{S} / \mathrm{cm}\end{array}$ & 1000 & 258 & 259 & 259 & 258 & 261 & 269 & 279 & 282 & 287 & 289 & 269 & 217 & 213 \\
\hline $\begin{array}{l}\text { Tot. res. aft. } \\
\text { evap. mg/l }\end{array}$ & & 129 & 129 & 129 & 129 & 130 & 134 & 139 & 141 & 143 & 144 & 139 & 108 & 106 \\
\hline $\mathrm{SO}_{4}{ }^{2-}, \mathrm{mg} / 1$ & 200 & 28,40 & 26,52 & 27,21 & 25,23 & 24,55 & 24,52 & 21,20 & 26,55 & 22,71 & 21,57 & 27,03 & 26,86 & 23,58 \\
\hline $\mathrm{NH}_{3}, \mathrm{mg} / \mathrm{l}$ & 0,10 & 0,014 & 0,005 & 0,010 & 0,007 & 0,023 & 0,008 & 0,008 & 0,010 & 0,007 & 0,007 & 0,010 & 0,008 & 0,010 \\
\hline $\mathrm{NO}_{2}^{-}, \mathrm{mg} / \mathrm{l}$ & $\mathbf{0 , 0 3}$ & 0,000 & 0,000 & 0,000 & 0,000 & 0,000 & 0,000 & 0,000 & 0,000 & 0,000 & 0,000 & 0,000 & 0,000 & 0,000 \\
\hline $\mathrm{NO}_{3}{ }^{-}, \mathrm{mg} / \mathrm{l}$ & 50 & 1,25 & 1,04 & 1,32 & 1,23 & 1,56 & 1,21 & 0,72 & 0,93 & 1,27 & 1,54 & 2,43 & 3,38 & 3,09 \\
\hline $\mathrm{Fe}, \mathrm{mg} / \mathrm{l}$ & $\mathbf{0 , 3 0}$ & 0.021 & 0,016 & 0,020 & 0,013 & 0,019 & 0,016 & 0,016 & 0,015 & 0,014 & 0,010 & 0,012 & 0,007 & 0.010 \\
\hline $\mathrm{Mn}, \mathrm{mg} / \mathrm{l}$ & 0,05 & 0,00 & 0,00 & 0,00 & 0,00 & 0,00 & 0,00 & 0,00 & 0,00 & 0,00 & 0,00 & 0,00 & 0,00 & 0,00 \\
\hline $\mathrm{Ca}, \mathrm{mg} / \mathrm{l}$ & & 32,73 & 31,91 & 30,83 & 29,59 & 30,16 & 30,14 & 31,82 & 33,15 & 32,86 & 32,82 & 31,67 & 24,53 & 23,9 \\
\hline $\mathrm{Cl}^{-}, \mathrm{mg} / \mathrm{l}$ & 200 & 3,51 & 3,56 & 3,59 & 3,65 & 3,57 & 3,36 & 3,39 & 3,46 & 3,47 & 3,46 & 3,89 & 3,74 & 3,77 \\
\hline $\begin{array}{c}\text { Residual. } \mathrm{Cl}_{2} \\
\mathrm{mg} / \mathrm{l}\end{array}$ & 0,5 & 0,44 & 0,46 & 0,44 & 0,43 & 0,44 & 0,39 & 0,44 & 0,38 & 0,43 & 0,40 & 0,37 & 0,39 & 0,33 \\
\hline Final $\mathrm{Cl}_{2}, \mathrm{mg} / \mathrm{l}$ & & 0,73 & 0,73 & 0,71 & 0,68 & 0,67 & 0,66 & 0,79 & 0,81 & 0,78 & 0,74 & 0,67 & 0,70 & 0,67 \\
\hline $\begin{array}{c}\text { Residual. Al, } \\
\text { mg/l }\end{array}$ & 0,20 & 0,040 & 0,089 & 0,092 & 0,075 & 0,061 & 0,070 & 0,085 & 0,053 & 0,025 & 0,024 & 0,028 & 0,018 & 0,044 \\
\hline
\end{tabular}

More precisely, the measured values for turbidity, electrical conductivity, sulphates, ammonia, nitrates, iron, and chlorides were significantly below the maximum allowed concentrations in drinking water, while $\mathrm{pH}$ was within the required range from 6.8 to 8.5 . Nitrites and manganese were not present in the treated water even in traces. Regardless of the increased turbidity after clarification due to increased raw water turbidity, the turbidity of the treated water was considerably below the allowed values, most often below 0.1 NTU during the observed period. In compliance with the Regulation, residual chlorine concentration ranged from $0.37 \mathrm{mgCl} / \mathrm{l}$ in March to $0.46 \mathrm{mgCl} / \mathrm{l}$ in June in the main chlorination and from $0.67 \mathrm{mgCl} / 1$ in September to $0.81 \mathrm{mgCl} / 1$ in December in the final chlorination. Generally, the average monthly values of characteristic parameters of treated water in the analyzed trial period are indicative of excellent drinking water quality. The presented analysis of trial run results for the water treatment plant "Gorina" in Leskovac, Serbia showcases the benefits of applying the equation of optimum coagulant doses to achieve top drinking water quality. Additionally, optimum coagulant doses leads to low-cost, low-energy and low-maintenance potable water production plant [10]. With no less importance is the fact that this approach leads to lesser environmental impacts and greater operation sustainability $[11,12]$.

\section{CONCLUSION}

The presented values of the parameters of treated water quality indicators during the one-year trial run of the water treatment plant "Gorina" in Serbia indicated that the plant designed for the treatment of raw water from the accumulation lake Barje to drinking water standard operates reliably and efficiently. The modern production line of the water treatment plant involves automatic dosing 
of the following chemicals: sulphuric acid for $\mathrm{pH}$ correction; ozone in pre-ozonation; aluminium sulphate as a coagulant; anionic polyelectrolytes as flocculants; lime for decarbonisation; and chlorine for disinfection. The flexible production line allows the process to adapt according to the quality of raw water through dosing of the optimum amount of chemicals. During the trial run, the production was carried out with negligible daily and monthly oscillations in water quantity, which was good in terms of lower consumption of chemicals on the one hand and higher quality of treated water on the other hand. The optimum coagulant dose during the operation of the water treatment plant "Gorina" was determined in a laboratory by means of the jar test, which fully simulates the conditions of flocculation chambers in the facility. Experimental data fitting yielded a polynomial equation that can use the determined coagulant doses to determine reduced turbidity values, which only slightly deviate from the measured values. An approximation error by the equation was expected, as it did not consider the significant impact of sample temperature and $\mathrm{pH}$ on the effect of coagulation. In general, without a jar test, the equation can be used to reliably determine the optimum coagulant dose for application in the water treatment plant, which will purify raw water to a proper inter-stage turbidity value, which will in turn guarantee that the treated water quality will ultimately comply with the Regulation on Hygienic Quality of Drinking Water. It should be noted that the experimental optimum coagulant dose of $26 \mathrm{~g} / \mathrm{m}^{3}$ applied in the water treatment process corresponds with the average dose applied during the trial run. It is certainly important to emphasize that the obtained values of the parameters indicators of the quality of the final water during the one-year trial work of the water treatment plant "Gorina" Leskovac in Serbia, indicate the reliability and efficiency of projected- treatment plant for processing raw water from the accumulation "Barje" to the quality of drinking water. The achieved top quality of treated water confirms that the applied purification technology - dosing the necessary amount of chemicals according to the raw water quality - produces water in accordance with drinking water quality standards.

\section{Acknowledgements}

The presented research is a part of the project No III 43014, TP 33034, III 42006 and III 44006 under the auspices of the Ministry of Education, Science and Technological Development, Republic of Serbia.

\section{REFERENCES}

[1] Ibrahim, S. H. (2017). Sustainability Assessment and Identification of Determinants in Community-Based Water Supply Projects using Partial Least Squares Path Model. Journal of Sustainable Development of Energy, Water and Environment Systems, 5(3), 345-348. https://doi.org/10.13044/j.sdewes.d5.0153

[2] European Commission. (2000). Directive 2000/60/EC of the European Parliament and of the Council of 23 October 2000 establishing a framework for Community action in the field of water policy - Water Framework Directive. Official Journal of European Union OJL 327. Retrieved from:http://ec.europa.eu/environment/water/waterframework/index_en.html
[3] Ministry for environmental protection. (2011). Rule on the parameters of the ecological and chemical status of surface waters and the parameters of the chemical and quantitative status of ground water. Official Gazette of the Republic of Serbia, No. 74/2011. Retrieved from: http://www.ekologija.gov.rs/dokumenti/

[4] Environmental Protection Agency. (2015). Annual report on surface and groundwater quality for 2014. Retrieved from: http://www.sepa.gov.rs/download/KvalitetVoda2014. pdf

[5] Energoprojekt - Hidroinženjering DD. (1992). Surface water treatment plant Gorina, Leskovac - Detailed Project, Book III: Processing-Technological Project. Belgrade, Serbia.

[6] Takić, Lj., Mladenović-Ranisavljević, I., Vasović, D., \& Đorđević, Lj. (2017). The Assessment of the Danube River Water Pollution in Serbia. Water, Air, \& Soil Pollution. Springer International Publishing. 228:380. https://doi.org/10.1007/s11270-017-3551-x

[7] Kim C. M. \& Parnichkun M. (2017). MLP, ANFIS, and GRNN based real-time coagulant dosage determination and accuracy comparison using full-scale data of a water treatment plant. Journal of Water Supply: Research and Technology - Aqua, 66(1), 49-61. https://doi.org/10.2166/aqua.2016.022

[8] European Environment Agency. Waterbase - lakes. Retrieved from: http://www.eea.europa.eu/data-and-maps/ data/waterbase-lakes.

[9] Regulation on Hygienic Quality of Drinking Water, Official Gazette of the Republic of Yugoslavia, No. 42/98, 44/99. Retrieved from:http://www.zjz.org.rs/wp-content/uploads/ 2013/04/pravilnik-o-higijenskoj-ispravnosti-vode-zapice.pdf

[10] Neamt, I. \& Ionel, I. (2013). Environmental management of the sewage sludge: case study - the wastewater treatment plant of Timisoara. Tehnički vjesnik, 20(3), 435-439.

[11] Soto, R., Crawford, B., Misra, S., Monfroy, E., Palma, W., Castro, C., \& Paredes, F. (2014). Constraint programming for optimal design of architectures for water distribution tanks and reservoirs: a case study. Tehnički vjesnik, 21(1), 99-105.

[12] Markov, Z., Jovanovski, I., \& Dimitrovski, D. (2017). Multicriteria analysis approach for selection of the most appropriate technology for municipal wastewater treatment. Journal of Environmental Protection and Ecology, 18(1), 289-303. Retrieved from http://www.jepe-journal.info/ journal-content

\section{Contact information:}

Ljiljana TAKIĆ, PhD, Associate Professor

University of Niš, Faculty of Technology in Leskovac, Serbia

Bulevar Oslobodjenja 124, 16000 Leskovac, Serbia

ljilja_t@yahoo.com

Dejan VASOVIĆ, PhD, Assistant Professor

(Corresponding author)

University of Niš, Faculty of Occupational Safety in Niš, Serbia

Čarnojevića 10A, 18000 Niš, Serbia

djnvasovic@gmail.com

Srdjan MARKOVIĆ, MSc, Chief of a Sector

Ministry of Defence, General logistic department,

Nemanjina 15, 11000 Belgrade, Serbia

markovic210@gmail.com

Zijah BURZIĆ, PhD, Chief of a Sector

Ministry of Defense, Military Technical Institute,

Ratka Resanovića 1, 11000 Belgrade, Serbia

zijah.burzic@vti.vs.rs 